\title{
The Economics and Spatial Analysis on How the Cash Transfer Ease the Poverty Condition
}

\author{
$1^{\text {st }}$ Ukhti Ciptawaty ${ }^{1}, 2^{\text {nd }}$ Mochamad Firman Ghazali $^{2}, 3^{\text {rd }}$ Resha Moniyana Putri $^{3}$, \\ $4^{\text {th }}$ Asih Murwiati ${ }^{4}$ \\ \{ukhti.ciptawaty@feb.unila.ac.id ${ }^{1}$, firman.ghazali@eng.unila.ac.id ${ }^{2}$, resha.moniyana@unila.ac.id3 \\ asih.mureati@unila.ac.id $\left.{ }^{4}\right\}$
}

Faculty Economy and Bussiness, Universitas Lampung, Jl. Prof. Dr. Ir. Sumantri Brojonegoro, No: 1, Gedong Meneng, Kec. Rajabasa, Kota Bandar Lampung, Lampung 35141 1,3,4, Department of Geodesy and Geomatics, Faculty Engineering, Universitas Lampung, Jl. Prof. Dr. Ir. Sumantri Brojonegoro, No:

1, Gedong Meneng, Kec. Rajabasa, Kota Bandar Lampung, Lampung $35141^{2}$

\begin{abstract}
This research investigates the community's poverty conditions before and after Cash Transfer Program (CTP) at the socioeconomic level of the people, located in Bandar Lampung City. The socio-economic level describes the total household expenditure in the area of cash transfer implementation. The data was obtained from the primary research and then processed statistically and analyzed by a "Kmeans clustered" is used to know the location of the recipient of cash transfer as the people below the poverty line. These methods are offering integration between the economics analysis with the spatial analysis. As statistically, it can be stated that the purpose of the cash transfer in improving the standard of living of beneficiary families through access to services education, health, and social welfare is achieved. Besides that, the "KMeans clustered" show several groups divided along with the study areas, which described the variation of living in an urban area.
\end{abstract}

Keywords: poverty, consumption, kmeans clustered, paired test, CTP.

\section{Introduction}

Adnyani[1] showed that the provinces of Lampung, DKI Jakarta, North Sumatra, West Sumatra, South Kalimantan, and West Nusa Tenggara had an average high value of poverty vulnerability. Lampung became the most vulnerable province in 2014. Besides, in this study, it was also found that the age of the head of the household, size of the house, education of the head of the family, ownership of savings, land ownership, and location had a significant influence on the value of vulnerability household poverty. Based on this research, it can be assumed that Lampung Province needs economic assistance from the government, for example, in the form of the Cash transfer. Therefore, this research focuses on the discussion in Bandar Lampung City as the provincial capital with a poverty rate of 14.76 percent in 2019 . The poverty rate is classified as high when compared to other regions on the island of Sumatra.

\subsection{Problems Recognition and Its Significance}

One of the benchmarks in welfare in Indonesia is reflected in poverty so that with poverty reduction, welfare in an area can be said to increase. Several studies have been conducted to find out the root causes of poverty. In Ghana, poverty can be seen from the economic structure (number of labor and total income per sector), human resources (age of workers, sex, fertility, number of educated population per level), infrastructure and environmental degradation [2]. Another example of a study conducted by on efforts to reduce poverty is by increasing poverty 
programs in Thailand. In it, there is a spatial relation (spatial) between poverty with the factors that cause poverty. Where the element of lack of income and assets (lack of income and assets) from the agricultural sector becomes the main in rural areas, on the other hand, urban areas no longer have agricultural characteristics but are spatially linked, and the authors want to detect and explain poverty [3]From what is said by [4],it can be concluded that poverty (proper) in cities occurs due to the powerlessness of city residents in accessing decent livelihoods to increase vulnerability in dealing with emergencies (state of emergency) but create some dependencies (dependence) on the [4].

The latest data from the Central Statistics Agency states that in September 2019, the number of poor people (residents with per capita expenditure per month below the Poverty Line) in Lampung reached 1.04 million people (12.30 percent) [5]. The percentage of low-income people in urban areas in March 2019 amounted to 8.92 percent, down to 8.60 percent in September 2019. The percentage decrease of the low-income families by 0.32 percent cannot be categorized as successful development. In fact, during the period March - September 2019, the number of low-income families in urban areas decreased by 7.17 thousand people (from 231.86 thousand people in March 2019 to 224.690 thousand people in September 2019), while in rural areas decreased by 15.01 thousand people (from 831.80 thousand people in March 2019 to 816.79 thousand people in September 2019). The decline in the number of low-income families in rural areas is 50 percent higher than the decrease in the name of the low-income families in urban areas. The condition indicates that urban, in this case, Bandar Lampung City, as the provincial capital, still has problems in poverty alleviation.

Cash transfer is one of the integrated programs between health and social. Cash transfer provides conditional cash assistance to Very Poor Households (VPH). Cash transfer participants fall into the inadequate criteria set by the Central Statistics Agency (BPS) and have dependents on pregnant women, infants under five years old in one impoverished household. This program is carried out to reduce poverty, break the poverty chain, improve the quality of human resources, and change the behavior of $\mathrm{VPH}$, relatively less supportive of promoting welfare. Cash transfer will provide income effects to VPH by reducing household expenditure burden in the short term.

Furthermore, poverty is closely related to the growth and development of slums-namely, the area of residence of residents who are below decent standards. Inside, many low-income residents are living. That situation results in not meeting the social, health, safety, and comfort needs of the people who live there and their ecological and legal administrative requirements. Although the standards of slums and non-slums have not been set yet, several characteristics appear to be such as the high level of density and the lack of open space between residents' houses [6]. Spatially recognized, the cash transfer recipients are closed to the configuration of the settlement. As satellite data proved that the settlement have several indicators, includes the characteristics of the roof material used, accessibility in the form of roads (land, asphalt and paving blocks), distance to the river and characteristics of the topography [7]. In line with [8], at least settlements near flooded areas, located on steep slopes, near highways or railroad tracks, SUTET, close to factories that have the potential to produce hazardous waste, can be indicated a slum environment. From this explanation, it is possible to have a relationship between slums, poverty, and the Cash transfer program's implementation. This research proposal identifies changes in consumption patterns of consumption of poor households after receiving cash assistance from the government. Observation of poverty conditions is done by taking into account the consumption expenditure of CTP recipient families using the paired test method. Furthermore, this research integrates slum distribution data generated from remote sensing data. 
As a result, spatial mapping of Cash transfer recipient mapping is obtained to see the current situation after the implementation of the cash transfer in Bandar Lampung City.

\subsection{Research questions}

Based on the explanation contained in the background above, the problem formulation in this research are: 1). What is the comparison of consumption patterns of low-income families before and after the cash transfer? and 2). How is the spatial mapping of cash transfer recipient low-income families in Bandar Lampung?

\subsection{Novelty of research}

This study aims to analyze the implementation of cash transfer at the socioeconomic level of the people belonging to the community groups below the poverty line, located in Bandar Lampung City. The study will investigate how cash transfer help to ease the poverty condition from the consumption expenditure point of view. Besides, this research will show the clustered of PKH recipient based on its distance and the amount of cash transfer received in a map as the basis of the spatial analysis. The results obtained from this study are expected to explain the effect of the implementation of cash transfer in the form of its contribution to the improvement of the social status of the community, along with its relation to the economics and spatial analysis for the poverty condition in those areas. However, the observation effect for a new government program is not smooth. The reason is due to the need for adequate data, sufficient resources, and continuous follow-up. On that say, this study tries to make an analysis both from economics and spatial point of views. In addition, provincial governments provided financial assistance to these designated poverty counties to enhance their consumption expenditure such as food and education spending.

\subsection{Objectives}

Based on the explanation contained in the background above, then the objectives of this study are: 1). Explain the comparison of consumption patterns of low-income families before and after the cash transfer and 2). Describe the spatial mapping of cash transfer recipient lowincome families in Bandar Lampung.

\section{LITERATURE REVIEW}

One of the Intergovernmental Transfers is an essential source of local public goods and services provided in many developing countries. Yet the empirical evidence on their effectiveness remains inconclusive partly because transfers are endogenous to political influence. This paper investigates the impact of a mix of intergovernmental transfers from a large-scale poverty relief program on local education spending in China between 1994 and 2000 [9]. From the same point of view, this study will investigate the impact of governmental transfers. Cash transfers program such as cash transfer in Bandar Lampung since the program was launched in 2011. Its application is an essential income for low-income families in fulfilling their need for consumption expenditure. In many developing countries, such as Indonesia, yet the empirical evidence on their effectiveness remains inconclusive partly because cash transfers are close to budget leakage in the government. This paper shares the same empirical purpose of what kind of changes the program creates in the household scale on consumption expenditure and map the spatial look of the low-income families based on the characteristics of the area.

Another journal that tried to see the efficiency of a government aid stated that one core objective most commonly cited to support aid programs is poverty reduction. In this paper, we estimate the allocation of assistance to maximize the reduction in poverty and compare it to actual distributions. Finally, they found that the actual allocation of aid is radically different 
from the poverty efficient allocation. With prompt delivery, support lifts around10 million people annually out of poverty in our sample of countries [10]. On that idea, this study shares the same intention to investigate how cash transfer may bring impact to the receiver.

\section{METHODOLOGIES AND DATA ANALYSIS}

\subsection{Study Location}

The study of the economics and spatial analysis on how the family hope program ease the poverty condition conducted in the city of Bandar Lampung, and took four sub-district as the samples, includes the Sukarame, Langkapura, Way Halim and Labuhan Ratu. The situation of these locations shows in the map below (Figure 1).

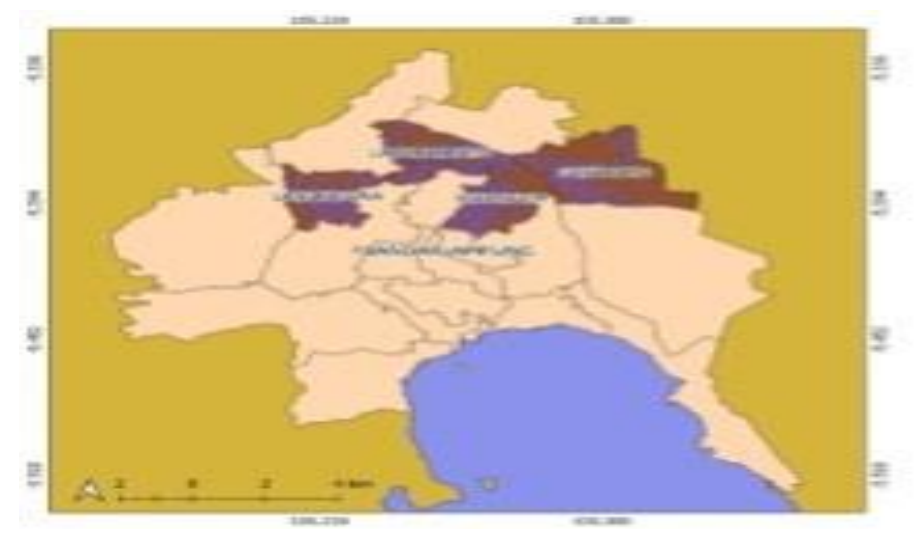

Figure 1. Map of Bandar Lampung and cash transfer recipient in four sub-districts

\subsection{Data}

This paper focuses on the county as the main unit of analysis for consumption expenditure both for food and education spending. Food and education expenditure have been playing a major role in financing and providing needs for the low-income families. The interviews from the survey indicates that food and education are the most supported expenditure from the cash transfer

The data was taken from the primary research in the form of interview and survey based on the Indonesia Family Life Survey (IFLS) typed questions. The sampling for the receiver of cash transfer was based on a randomized, community-based intervention with measurements before and after the intervention of the program. There are four district investigated in this study; Sukarame, Langkapura, Way Halim and Labuhan Ratu. Those sub-districts have the most collected number of low-income families. The spatial data of cash transfer recipient has produced by converting the tabular data into shape file format. It has 904 numbers of cash transfer recipient and spread out in four sub-districts.

\section{3. Paired t Test Using Stata}

The paired sample t-test, sometimes called the dependent sample t-test, is a statistical procedure used to determine whether the mean difference between two sets of observations is 
zero. The paired t-test, also referred to as the paired-samples t-test or dependent t-test, is used to determine whether the mean of a dependent variable is the same in two related groups.

\subsubsection{Paired t Test Assumptions}

There are four assumptions that underpin the paired t-test; (1) the dependent variable should be measured at the interval or ratio level, (2) the independent variable should consist of two categorical, "related groups" or "matched pairs"; (3) there should be no significant outliers in the differences between the two related groups; and (4) the distribution of the differences in the dependent variable between the two related groups should be approximately normally distributed.

\subsubsection{The guidelines for decision making in Paired T-Test Test}

According to guidelines for decision making in the paired t-test based on the significance value (Sig) of Stata output results. If the Sig. (2-tailed) $<0.05$, then $\mathrm{H} 0$ is rejected, and $\mathrm{Ha}$ is accepted. And conversely, if the value of Sig. ( 2 tailed) $>0.05$, then $\mathrm{HO}$ is accepted, and $\mathrm{Ha}$ is rejected. In addition to comparing the significance value ( $\mathrm{Sig}$ ) with a probability of 0.05 , another way to test the hypothesis in the paired-sample t-test is to examine the calculated t value with $t$ table.

\subsubsection{Hypothesis}

$\mathrm{H} 0=$ There is no difference in consumption expenditure after funding assistance from the cash transfer and $\mathrm{Ha}=$ There is a difference in consumption expenditure after funding assistance from the cash transfer.

\section{RESEARCH RESULT AND DISCUSSION}

\section{1. Education Expenditure}

Table 1. Paired t test Result for Education Expenditure

\begin{tabular}{|c|c|c|c|c|c|c|}
\hline Variable & Obs & Mean & Std. Err. & Std. Dev. & [95\% Conf. & Interval] \\
\hline alat_s e | & 40 & 1705500 & 938226.6 & 5933866 & -192242.5 & 3603243 \\
\hline alat_s $\sim \mathrm{r}$ & 40 & 2721500 & 1477444 & 9344176 & -266912.5 & 5709913 \\
\hline diff & 40 & -1016000 & 550043.4 & 3478780 & -2128568 & 96567.89 \\
\hline
\end{tabular}

Source: Data Calculated

Table 2. Mean Difference for Education Expenditure

\begin{tabular}{|c|c|c|c|}
\hline \multicolumn{4}{|c|}{ mean $($ diff $)=$ mean $($ school stationary_b e - school stat_a $\sim$ r) } \\
\hline \multicolumn{4}{|c|}{$\begin{array}{c}\text { Source: Data Calculated } \\
\text { Table 3. T value for Education Expenditure }\end{array}$} \\
\hline Ha: mean(diff) $<0$ & Ha: mean(diff) $!=0$ & Ha: $\operatorname{mean}($ diff $)>0$ & \\
\hline $\operatorname{Pr}(\mathrm{T}<\mathrm{t})=0.0362$ & $\operatorname{Pr}(|\mathrm{T}|>|\mathrm{t}|)=0.0723$ & $\operatorname{Pr}(\mathrm{T}>\mathrm{t})=0.9638$ & \\
\hline
\end{tabular}

There is a founding shows that $\mathrm{T}$ value $>\mathrm{t}$ table, then some of the necessary returns on the decision can be concluded that $\mathrm{HO}$ is rejected and $\mathrm{Ha}$ is accepted. So it can be found that there is an average difference between spending on education consumption before and after aid for unconditional fund transfer (Table 1). The situation indicates that assistance from conditional fund transfers provides benefits to increase use in the form of education expenditure. Here expected the Cash transfer to provide a positive stimulus to meeting needs. Therefore, a difference in education expenditure after funding assistance from the cash transfer will ease the poverty conditions of low-income families. At least, it can be stated that the purpose of the 
organization in improving the standard of living of beneficiary families through access to services education, health, and social welfare is achieved (Table 2). The result of the study supports the idea stated by showing the empirical evidence suggests that, despite the intergovernmental transfers that resulted in more significant financial resources to local governments for education provision [9]. Although these measures indicate only budgetary expenditures on education and not the total education spending figures (Table 3).

\subsection{Food Expenditure}

Table 4. Paired t test Result for Food Expenditure

\begin{tabular}{|l|ccccll|}
\hline Variable & Obs & Mean & Std. Err. & Std. Dev. & [95\% Conf. & Interval] \\
\hline rice_b e | & 40 & 22.35 & .7816403 & 4.943527 & 20.76898 & 23.93102 \\
rice_a r | & 40 & 25.7 & 1.065905 & 6.741376 & 23.544 & 27.856 \\
diff $\quad$ | & 40 & -3.35 & 1.218211 & 7.704644 & -5.814065 & -.8859353 \\
\hline
\end{tabular}

Source: Data Calculated

Table 5. Mean Difference for Food Expenditure

\begin{tabular}{|lrl|}
\hline mean $($ diff $)=$ mean(rice_before - rice_after) $\quad t=$ & -2.7499 \\
\hline Ho: mean $($ diff $)=0 \quad$ degrees of freedom $=$ & 39 \\
\hline
\end{tabular}

Source: Data Calculated

Table 6. T value for Food Expenditure

\begin{tabular}{|lcc|}
\hline Ha: mean $($ diff $)<0$ & Ha: mean $($ diff $) !=0$ & Ha: mean $($ diff $)>0$ \\
\hline $\operatorname{Pr}(\mathrm{T}<\mathrm{t})=0.0045$ & $\operatorname{Pr}(|\mathrm{T}|>|\mathrm{t}|)=0.0090$ & $\operatorname{Pr}(\mathrm{T}>\mathrm{t})=0.9955$ \\
\hline
\end{tabular}

Source: Data Calculated

One of the objectives of providing conditional cash transfers is to reduce poverty and disparity between income groups. According to [11], in the short term, Cash transfers serve to reduce the burden of household expenditure from VPH. Based on the results $\mathrm{T}$ value $>\mathrm{t}$ table, some of the necessary returns on the decision can be concluded that $\mathrm{HO}$ is rejected and $\mathrm{Ha}$ is accepted (Table 4). So it can be found that there is an average difference between spending on food consumption before and after aid for conditional fund transfer. Family satisfaction appears to have received a significant and positive impact from the CTP program. CTP may also help beneficiaries maintain stable consumption levels during short-term economic shocks, but future perception and children's well-being perception are not found to be affected [12]. Next, it may lead to help the insufficient fulfillment of food and increase the basic needs' use of low-income and vulnerable families. By then, it can be stated that one of the purposes of CTP is achieved (Table 5-6).

\section{3. KMeans Clustered of PKH}

KMeans is naturally a mathematical model for grouping objects based on the specific criteria. The distance of each objects always use as the basis for developing a centroid or center for each group. Besides that, the group develops based on the similarity of criteria [13]. This study shows the KMeans developed based on the amount cash transferred. There are five clustered of PKH recipient that shows the groups in the study areas. For Langkapura and Labuhan Ratu sub-district, both have similar groups that received 225.000 to 3000.000 rupiah. For Sukarame and Way Halim sub-district, both have two groups and received 225.000 to 2.625.000 rupiah (Figure 2). These results can be interpreted as in Langkapura and Labuhan ratu sub-district may have similar social economy condition, while in Sukarame and Way Halim sub-district the same indicator may slightly different. It means in an urban areas the effort and some basic needs are different from in a sub urban area. This analysis is not good enough; it still 
requires a deep interpretation, especially why living in an urban area more difficult than in a sub-urban area.

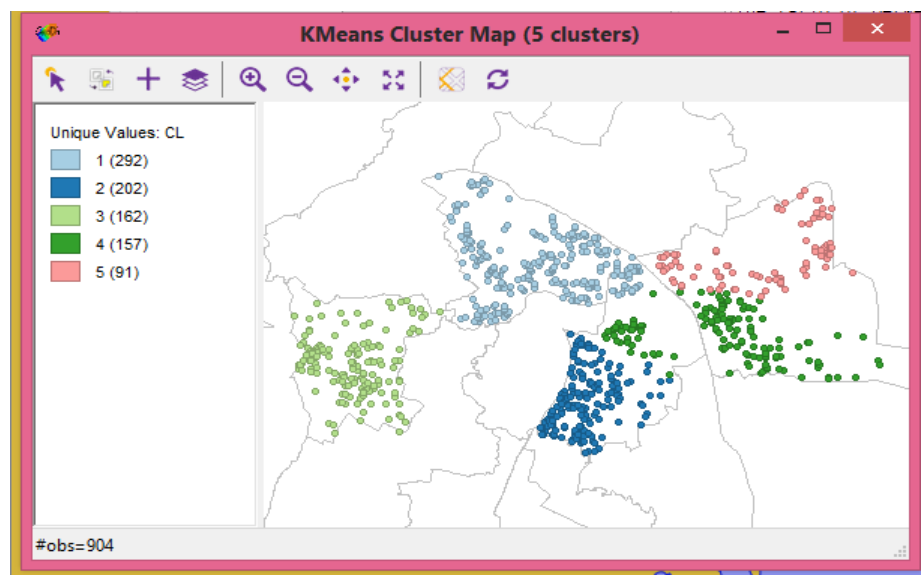

Figure 3 Clustered map of cash transfer recipient based on amount cash transferred

\section{SUMMARY}

Based on paired t-test analysis, it was found that consumption in the form of education and food expenditure has different mean values. The difference indicates that the use of Cash transfers is following the goals of the organization. As spatially gave a view of variation of standard cash transfer, it seems necessary to consider the urban structure as one of difficulties factor for living in an urban areas. This simple KMeans clustered given the spatial pattern on how the recipient are locate in the spatial context. The research is comprehensive for both economic and spatial analysis although it does not tell directly on economic matter, but it indicates the variation of living in an urban area.

\section{IMPLICATIONS / LIMITATIONS AND SUGGESTIONS FOR FURTHER RESEARCH}

Although aid may be allocated coherently, it is allocated inefficiently concerning poverty reduction. Currently, funding is allocated partly as an inducement to policy reform and partly for targeting weak policy environments.

\section{REFERENCES}

[1] A. W. Adnyani and L. Sugiharti, "Profil dan Determinan Kerentanan Kemiskinan Rumah Tangga di Indonesia,” J. Ilmu Ekon. Sos., vol. 10, no. 2, pp. 100-118, 2019.

[2] T. Tanaka and J. J. Lee, "Spatial analysis of poverty: Combining geospatial data and survey data to study regional inequality in Ghana," World Bank, p. 32, 2011.

[3] R. Thongdara, L. Samarakoon, R. P. Shrestha, and S. L. Ranamukhaarachchi, "Using GIS and Spatial Statistics to Target Poverty and Improve Poverty Alleviation Programs: A Case Study in Northeast Thailand," Appl. Spat. Anal. Policy, vol. 5, no. 2, pp. 157-182, 2012, doi: 10.1007/s12061-011-9066-8.

[4] L. Soc, "Et Al Et Al," vol. 44, no. 2, pp. 79-89, 2007.

[5] Badan Pusat Statistik, Kota Bandar Lampung dalam Angka 2020. Bandar Lampung, 2020.

[6] R. Mahabir, A. Crooks, A. Croitoru, and P. Agouris, "The study of slums as social and 
physical constructs: Challenges and emerging research opportunities," Reg. Stud. Reg. Sci., vol. 3, no. 1, pp. 399-419, 2016, doi: 10.1080/21681376.2016.1229130.

[7] S. Jain, "Approaches for Extraction of Slum Area From," Dehradun, 2010. doi: 10.1682/JRRD.2008.09.0127.

[8] D. Kohli, R. Sliuzas, and A. Stein, "Urban slum detection using texture and spatial metrics derived from satellite imagery," J. Spat. Sci., vol. 61, no. 2, pp. 405-426, 2016, doi: 10.1080/14498596.2016.1138247.

[9] X. Lü, "Intergovernmental transfers and local education provision - Evaluating China's 87 National Plan for Poverty Reduction," China Econ. Rev., vol. 33, pp. 200-211, 2015, doi: 10.1016/j.chieco.2015.02.001.

[10] P. Collier and D. Dollar, "Aid allocation and poverty reduction," Eur. Econ. Rev., vol. 46, no. 8, pp. 1475-1500, 2002, doi: 10.1016/S0014-2921(01)00187-8.

[11] K. P. P. N. Bappenas, "Kedeputian Bidang Kependudukan dan Ketenagakerjaan Kementerian PPN/Bappenas," 2018.

[12] A. A. Khomaini, "Dampak Program Bantuan Tunai (Cash Transfer) Terhadap Kesejahteraan Subjektif Di Indonesia," J. Perbendaharaan, Keuang. Negara Dan Kebijak. Publik, vol. 5, pp. 1-16, 2020.

[13] S. S. Durduran, "Automatic classification of high resolution land cover using a new data weighting procedure: The combination of $\mathrm{k}$-means clustering algorithm and central tendency measures ( KMC-CTM )," Appl. Soft Comput., vol. 35, pp. 136-150, 2015, doi: 10.1016/j.asoc.2015.06.025. 